\title{
Lipid Oxidation and Color Changes of Fresh Camel Meat Stored Under Different Atmosphere Packaging Systems
}

\section{Jouki* and N Khazaei}

Young Researchers Club, Islamic Azad University, Shahr-e-qods Branch, Tehran, I. R. Iran, P.O. Box: 37515-374

\begin{abstract}
Lipid oxidation, color and sensory attributes of fresh camel meat stored at $4^{\circ} \mathrm{C}$ were affected by modified atmosphere packaging conditions (AP: Air packaging, VP: Vacuum packaging, MAP: $60 \% \mathrm{CO} 2+40 \%$ N2). The $a^{*}$ value were lower in samples packed under vacuum than in the other groups. Modified atmosphere packaging camel meat had no significantly $(P<0.05)$ different TBARS value and the levels of TBARS were not positively correlated with storage time. Our study showed that even though oxidative rancidity (TBARS) increased with storage time in air-packaged samples, it did not result the deterioration of sensory quality until day 14 . Sensory panel results were in general agreement with the physicochemical changes, suggesting that the MAP had a significant impact on the quality of refrigerated camel meat. Modified atmosphere packaging of fresh camel meat accompanied by refrigeration storage enhanced product shelf life for 21 days without undesirable and detrimental effects on its sensory acceptability.
\end{abstract}

Keywords: Oxidation; Camel; Sensory evaluation; Color

\section{Introduction}

Extension of the shelf-life of meat was one of the technological necessities to meet the demands of consumers. In this respect, increasing attention was put on packaging techniques. Modified atmosphere packaging (MAP) is the recent innovation that has been gaining importance as preservation technique to improve the shelflife of meat. Retention of meat color was better in MAP than in either vacuum packaging or in air [1]. Modified atmosphere packing has been used for increased distribution range and longer shelf-life. The effects and roles of the gases normally used in the modified atmospheres $\left(\mathrm{O}_{2}\right.$, $\mathrm{CO}_{2}$ and $\mathrm{N}_{2}$ ) have been extensively reported [2-4]. Hood and Mead (1995) indicated that the effects which the mixture of gas produces in meat quality, such as color and shelf life, are the principal factors that should be considered when choosing the gas mixture [5]. In addition, Gill affirmed that the principal factors to be addressed in the preservation of chilled meat are the retention of an attractive, fresh appearance for the product displayed, and the retardation of bacterial spoilage [3]. Several studies have been carried out on the physical, chemical composition, sensory properties and nutritive values of camel meat [6-11]. No data has been published on the preservation of fresh camel meat by modified atmosphere packaging. Our objective was to investigate the color and lipid oxidation changes of fresh camel meat using modified atmosphere packaging under refrigeration.

\section{Material and Methods}

\section{Sampling preparation and packaging}

Camel meat samples were obtained at a slaughter house (Tehran, Iran). Any visible fat was removed from the muscle tissues. A Turbovac packaging machine, model A 200, (Henkelman, Netherlands) was used for packing. Meat samples were randomly assigned to one of the three types of different atmospheres packaging (AP: Air packaging, VP: Vacuum packaging, MAP: $60 \% \mathrm{CO}_{2}+40 \% \mathrm{~N}_{2}$ ) using sterile polyester polyethylene (PET/Poly) pouches (thickness $-62 \mathrm{~lm}$ ).

\section{Lipid oxidation}

Lipid oxidation was evaluated by the determination of thiobarbituric acid reactive substances (TBARS) using the extraction method described by Witte, et al. [12]. Twenty grams of the minced meat were blended with $50 \mathrm{~mL}$ of cold solution containing $20 \%$ trichloroacetic acid in $2 \mathrm{M}$ phosphoric acid for $2 \mathrm{~min}$. The resulting slurry was then transferred into a $100 \mathrm{~mL}$ volumetric flask. The slurry was diluted to $100 \mathrm{~mL}$ with double-distilled water, homogenized by shaking and filtered through Whatman no. 1 filter paper. $5 \mathrm{~mL}$ of the filtrate was then pipetted into a test tube and $5 \mathrm{~mL}$ of fresh chilled 2-thiobarbituric acid ( $0.005 \mathrm{M}$ in double distilled water) was added. The test tube was shaken well and placed in the dark at room temperature $\left(25^{\circ} \mathrm{C}\right)$ for 15 $\mathrm{h}$ to develop the color reaction. The resulting color was measured in a spectrophotometer at $530 \mathrm{~nm}$ to calculate the TBARS value. The results were expressed as mg malonaldehyde/kg meat.

\section{Color measurement}

Color was recorded using a Minolta Chroma meter CR-400 KON made in Japan. Readings at per sample, in the center of the steak was taken. CIELAB system, $\mathrm{L}^{*}$ (lightness), $\mathrm{a}^{*}$ (redness) and $\mathrm{b}^{*}$ (yellowness) were measured [13].

Chroma ( $c^{\star}$ ab) wascalculated asEq. $(1): C^{\star} a b=\left[\left(a^{\wedge}\left({ }^{\star} 2\right)+b^{\wedge}\left({ }^{\star} 2\right)\right)\right]^{\wedge}(1 / 2)$

Furthermore, the hue angle $\left(h^{\star} a b\right)$ was calculated as Eq. (2): $h^{\star} a b=\operatorname{arch} \tan \left(b^{\star} / a^{\star}\right)$

\section{Sensory analysis}

Camel meat samples were evaluated by eight semi-trained panelists. The panelists consisted of staff members in the Dept. of Meat Science, University of Tehran. Panelists were given an orientation for

*Corresponding author: M.Jouki, Young Researchers Club, Islamic Azad University, Shahr-e-qods Branch, Tehran, I. R. Iran, P.O. Box: 37515-374, India E-mail:m.jouki@yahoo.com

Received August 29, 2012; Accepted September 26, 2012; Published October 04,2012

Citation: Jouki M, Khazaei N (2012) Lipid Oxidation and Color Changes of Fresh Camel Meat Stored Under Different Atmosphere Packaging Systems. J Food Process Technol 3:189. doi:10.4172/2157-7110.1000189

Copyright: ( 2012 Jouki M, et al. This is an open-access article distributed under the terms of the Creative Commons Attribution License, which permits unrestricted use, distribution, and reproduction in any medium, provided the original author and source are credited. 
30 min about appearance (color), odor, texture and overall quality of fresh camel meat. Acceptability of raw meat was evaluated using a 9-point hedonic scale, where $9=$ like extremely, $8=$ like very much, $7=$ like moderately, $6=$ like slightly, $5=$ neither like nor dislike, $4=$ dislike slightly, $3=$ dislike moderately, $2=$ dislike very much, and $1=$ dislike extremely [14]. Scores from 6 to 9 were considered acceptable [15]. Evaluation was performed under cool white fluorescent light in the sensory laboratory. The same meat samples were evaluated over storage times. The shelf life limit was defined as the point when $50 \%$ of the panelists rejected the sample.

\section{Statistical analysis}

The data were analyzed using analysis of variance to determine the effects of MA type (1,2,3, and 4) on the parameters of meat quality: color, lipid oxidation and SF. When the differences among types of MA were significant $(\mathrm{P}<0.05)$, Tukey's test was carried out to check the differences between pairs of groups. The effect of storage for each treatment packing on meat quality was analyzed using Tukey's test at a significance level of $\mathrm{P}<0.05$. Data were analyzed using the SAS (1988) statistical package [16]

\section{Results and Discussions}

\section{Lipid oxidation}

TBARS values for different atmosphere packaged camel meat samples are shown in figure 1. Duration of the storage affected the overall TBARS formation of the meat $(\mathrm{P}<0.01)$. The amounts of malondialdehyde (MDA) increased during chilled storage with significant difference $(\mathrm{P}<0.05)$. Time had significant influence $(\mathrm{P}<0.01)$ on the development of oxidation in aerobically packaged camel similarly to the anaerobically packaged (Figure 1).The amounts of MDA formed during chilled storage were in the range $0.20-0.28 \mathrm{mg} /$ $\mathrm{kg}$ meat and reached 0.58 and $89 \mathrm{mg} / \mathrm{kg}$ meat for MA-Packaging and Air-Packaging on the $21^{\text {st }}$ day respectively, indicating a low degree of lipid oxidation. Modified atmosphere packaging camel meat had not significantly $(\mathrm{P}<0.05)$ different TBARS value and the levels of TBARS weren't positively correlated with storage time. After 21 days of storage the highest TBARS values were found in AP. A comparison was made between the values of the TBARS formed in the common intervals of the three types of storage of camel meat samples. Air-Packaged samples showed higher content of TBARS when subsequently chilled, compared to the vacuum-packaged and MA-Packaged meat. In AP, VP and MAP, the amounts of TBARS formed in the course of storage were far below the critical value of $3 \mathrm{mg} / \mathrm{kg}$ at which rancidity is detected

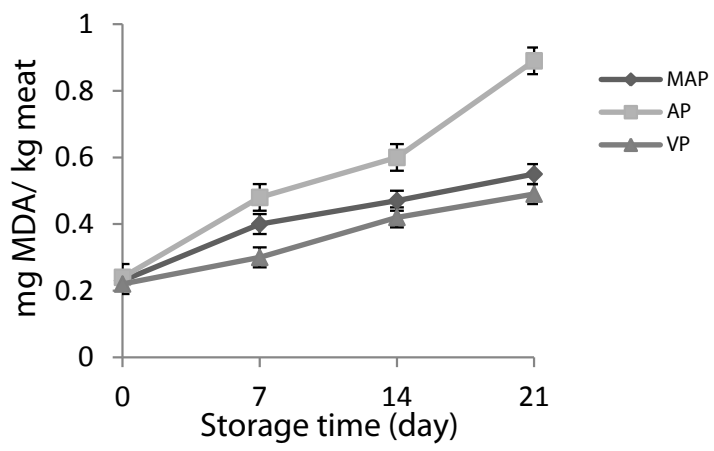

Figure 1: Development of lipid oxidation of camel meat stored in different atmospheres packaging during storage time.
[17]. It could be supposed that the low intensity of oxidative processes was due to the raising mode of the studied animals which provided natural antioxidants, such as vitamin E, carotenoids, etc. [18]. It was shown that pasture [19] increased significantly the content of vitamin $\mathrm{E}$ in bovine muscles and hence reduces the development of oxidation in meat.

\section{Color}

Results of color measurement are shown in (Table 2). Initial values for $\mathrm{L}^{*}, \mathrm{a}^{\star}, \mathrm{b}^{*}$ and Chroma were 34.49, 20.12, 7.59 and 22.74 respectively. The $\mathrm{L}^{\star}$ value increase by 21 days with time in all groups and reached significant levels $(\mathrm{P}<0.05)$ in $\mathrm{AP}$, with this usually being attributed to the oxidation of heme pigments [20]. The lowest $L$ values after 21 days corresponded to samples under Vacuum packaging which showed significant differences with samples under Air. Parameter $b^{*}$ (yellowness) increased by 21 days for of storage only in for camel meat during storage under Air, but no significant differences were found among samples packed under vacuum and MAP at the end of 21 days for yellowness. Differences in $b^{*}$ along the storage period could be related to the intensity of the oxidation process that takes place during storage and might tend to increase yellowness of samples by rancidity, although no measures of oxidation intensity are available to support this hypothesis. The $\mathrm{a}^{*}$ (redness) value in Air-Pakaging decreased significantly $(\mathrm{P}<0.01)$ at the same storage time. On the other hand, a decrease in $\mathrm{a}^{*}$ values due to oxygen content in AP would reflect myoglobin oxidation. Mercier et al. (1998), have observed an increase in the hue angle $\left(\operatorname{arc} \tan b^{*} / a^{*}\right)$ of stored turkey pectorals muscle, suggesting a degree of change from red to yellow, an indication of increased oxidation with time [21]. In the present study, calculation of hue angle values (not reported) showed an increase for Air-Packaged camel meat during storage, whereas in Vacuum-Packaged samples, values for camel meat remained relatively stable. The more rapid changes in $L^{*}, a^{*}$ and $b^{\star}$ value of Air Packaged samples suggest that this gas is responsible for the determination of colour. Moore and Gill (1987) also found increases in $L^{*}$ and $b^{*}$ values with time, in agreement with our results [22]. The increase in $b^{\star}$ may be associated with the transformation of the meat pigment and the formation of meat myoglobin, which is faster at relatively low oxygen concentration [23]. Our results show that a mixture with $30 \% \mathrm{CO}_{2}$ and $70 \% \mathrm{~N} 2$ maintains a good colour for up to 21 days at $4 \pm 11^{\circ} \mathrm{C}$ in the absence of $\mathrm{O}_{2}$. Chroma showed an opposite co-variation with $\mathrm{L}^{*}$. In both parameters there were significant differences among groups only from 21 days onward. The forward stepwise logistic regression model of acceptance was statistically significant $(\mathrm{P}<0.01)$ and showed that this acceptance was affected $(\mathrm{P}<0.01)$ by Chroma, time storage and MAP. Samples stored under MAP gases were accepted for a longer time than the other groups. Gas composition in packs (Table 1) was associated with the changes in colour and the probability of being accepted. In agreement with other authors [24] our study found a slower discoloration of samples stored with higher proportions of $\mathrm{CO}_{2}$, this being more evident in MAP treatment.

\section{Sensory analysis}

The camel meat was evaluated for changes in surface color, texture, and odor by semi-trained panelists. By the end of the storage time (at day 21), MAP were acceptable (scores $>6$ ) and significant differences $(\mathrm{P}<0.05)$ were found between other packaging system for all sensory attributes. The surface color of the samples in MAP was not severely discolored and remained acceptable even after 21 days storage. Storage time effect within treatment indicated that surface discoloration increased $(\mathrm{P}<0.05)$ especially at day 14 in Air-Packaged samples (Table 2). At day 21, surface colour of samples packed with MAP remained 


\begin{tabular}{|c|c|c|c|c|}
\hline $\begin{array}{l}\text { Treatment } / \\
\text { Time }\end{array}$ & & MAP & AP & VP \\
\hline \multirow[t]{4}{*}{$L^{*}$} & Day 1 & $33.89 \pm 0.89 \mathrm{~d}$ & $32.90 \pm 0.45 \mathrm{~d}$ & $34.59 \pm 1.01 \mathrm{c}$ \\
\hline & Day 7 & $34.69 \pm 1.32 \mathrm{c}, \mathrm{x}$ & $34.69 \pm 0.62 c, x$ & $35.66 \pm 0.29 b c, y$ \\
\hline & Day 14 & $37.65 \pm 0.95 a, x$ & $35.29 \pm 1.04 b, z$ & $36.08 \pm 1.14$ a,y \\
\hline & Day 21 & $35.32 \pm 0.59 \mathrm{~b}, \mathrm{y}$ & $37.21 \pm 0.70 a, x$ & $35.31 \pm 0.39 \mathrm{~b}, \mathrm{y}$ \\
\hline \multirow[t]{4}{*}{$\mathbf{a}^{*}$} & Day 1 & $19.90 \pm 0.71 \mathrm{a}, \mathrm{x}$ & $18.30 \pm 0.55 a, y$ & $19.83 \pm 0.87 a, x y$ \\
\hline & Day 7 & $18.81 \pm 0.40 \mathrm{ab}, \mathrm{x}$ & $16.73 \pm 0.63 b, y$ & $18.70 \pm 0.40 \mathrm{ab}, \mathrm{x}$ \\
\hline & Day 14 & $17.42 \pm 0.78 b, y$ & $13.50 \pm 0.38 \mathrm{c}, \mathrm{z}$ & $18.48 \pm 0.45 a b, x$ \\
\hline & Day 21 & $16.54 \pm 0.38 \mathrm{c}, \mathrm{xy}$ & $12.84 \pm 0.49 \mathrm{~d}, \mathrm{y}$ & $17.22 \pm 0.26 b, x$ \\
\hline \multirow[t]{4}{*}{$\mathbf{b}^{*}$} & Day 1 & $7.90 \pm 0.35 b$ & $8.58 \pm 0.50 \mathrm{c}$ & $8.17 \pm 0.44 b$ \\
\hline & Day 7 & $8.17 \pm 0.29 \mathrm{ab}, \mathrm{y}$ & $9.39 \pm 0.64 \mathrm{bc}, \mathrm{x}$ & $8.20 \pm 0.63 b, y$ \\
\hline & Day 14 & $8.35 \pm 0.52 a b, y$ & $10.48 \pm 0.55 b, x$ & $9.13 \pm 0.36 a b, x y$ \\
\hline & Day 21 & $8.88 \pm 0.39 a, y$ & $12.10 \pm 0.48 \mathrm{a}, \mathrm{x}$ & $9.37 \pm 0.42 \mathrm{a}, \mathrm{y}$ \\
\hline \multirow[t]{4}{*}{ Chroma } & Day 1 & $21.92 \pm 0.55 a, x y$ & $20.19 \pm 0.46 a, y$ & $22.11 \pm 0.42 \mathrm{a}, \mathrm{x}$ \\
\hline & Day 7 & $21.14 \pm 0.37 a b, x y$ & $19.53 \pm 0.49 \mathrm{a}, \mathrm{y}$ & $21.57 \pm 0.46 a b, x$ \\
\hline & Day 14 & $19.86 \pm 0.75 b, y$ & $18.07 \pm 0.55 b, z$ & $20.90 \pm 0.39 a b, x$ \\
\hline & Day 21 & $19.62 \pm 0.33 b, x y$ & $17.70 \pm 0.45 b, y$ & $20.37 \pm 0.82 b$ \\
\hline
\end{tabular}

$a, b, c$ values in the same column with different superscripts are significantly different $(p<0.05) . x, y, z$ values in the same row with different superscripts are significantly different $(p<0.05)$. MAP: modified atmosphere packaging, AP: Air packaging, VP: Vacuum packaging

Table 1: Mean \pm SD of Values of colour $\left(L^{*}, a^{*}\right.$ and $\left.b^{*}\right)$ of camel meat stored in different atmospheres packaging during storage time.

\begin{tabular}{|l|c|c|c|c|}
\hline Treatment / Time & & MAP & AP & VP \\
\hline Appearance & Day 1 & $8.19 \mathrm{a}$ & $7.86 \mathrm{a}$ & $8.10 \mathrm{a}$ \\
\hline & Day 7 & $7.91 \mathrm{a}, \mathrm{x}$ & $6.19 \mathrm{~b}, \mathrm{y}$ & $7.45 \mathrm{ab}, \mathrm{xy}$ \\
\hline & Day 14 & $7.45 \mathrm{a}, \mathrm{x}$ & $5.88 \mathrm{c}, \mathrm{y}$ & $7.13 \mathrm{ab}, \mathrm{x}$ \\
\hline Odor & Day 21 & $6.80 \mathrm{a}, \mathrm{x}$ & $4.38 \mathrm{~d}, \mathrm{y}$ & $5.81 \mathrm{~b}, \mathrm{xy}$ \\
\hline & Day 1 & $7.88 \mathrm{a}$ & $7.75 \mathrm{a}$ & $7.91 \mathrm{a}$ \\
\hline & Day 7 & $7.62 \mathrm{a}, \mathrm{x}$ & $7.03 \mathrm{ab}, \mathrm{y}$ & $7.54 \mathrm{ab}, \mathrm{x}$ \\
\hline & Day 14 & $7.02 \mathrm{a}, \mathrm{x}$ & $6.19 \mathrm{~b}, \mathrm{y}$ & $6.90 \mathrm{ab}, \mathrm{x}$ \\
\hline Texture & Day 21 & $6.67 \mathrm{a}, \mathrm{x}$ & $5.86 \mathrm{~b}, \mathrm{y}$ & $5.91 \mathrm{~b}, \mathrm{y}$ \\
\hline & Day 1 & $8.70 \mathrm{a}$ & $8.40 \mathrm{a}$ & $8.70 \mathrm{a}$ \\
\hline & Day 7 & $7.90 \mathrm{ab}$ & $7.61 \mathrm{ab}$ & $8.00 \mathrm{ab}$ \\
\hline & Day 14 & $7.00 \mathrm{bc}, \mathrm{x}$ & $6.57 \mathrm{~b}, \mathrm{y}$ & $7.10 \mathrm{bc}, \mathrm{x}$ \\
\hline & Day 21 & $6.60 \mathrm{c}, \mathrm{x}$ & $5.54 \mathrm{~b}, \mathrm{z}$ & $5.90 \mathrm{c}, \mathrm{y}$ \\
\hline Overall Quality & Day 1 & $8.43 \mathrm{a}$ & $8.31 \mathrm{a}$ & $8.64 \mathrm{a}$ \\
\hline & Day 7 & $7.60 \mathrm{ab}, \mathrm{xy}$ & $6.89 \mathrm{~b}, \mathrm{y}$ & $7.91 \mathrm{ab}, \mathrm{x}$ \\
\hline & Day 14 & $6.97 \mathrm{~b}, \mathrm{x}$ & $5.99 \mathrm{c}, \mathrm{y}$ & $6.62 \mathrm{~b}, \mathrm{xy}$ \\
\hline & Day 21 & $6.61 \mathrm{~b}, \mathrm{x}$ & $4.96 \mathrm{~d}, \mathrm{z}$ & $5.87 \mathrm{c}, \mathrm{y}$ \\
\hline
\end{tabular}

$a, b, c, d$ values in the same column with different superscripts are significantly different $(p<0.05)$

$x, y, z$ values in the same row with different superscripts are significantly different $(p<0.05)$

MAP: modified atmosphere packaging, AP: Air packaging, VP: Vacuum packaging.

Table 2: Sensory attributes of camel meat stored in different atmospheres packaging during storage time.

unchanged $(\mathrm{P}>0.05)$. The data suggest that the MAP with high $\mathrm{CO}_{2}$ protected the surface color. The colour and odor changes in meats are highly dependent upon packaging condition [25]. Panelists rejected Air-Packaged samples after 14 days storage at $4^{\circ} \mathrm{C}$ but MAP increased the shelf life of fresh camel meat refrigerated at $4^{\circ} \mathrm{C}$ by more than 21 days.

\section{Conclusion}

In this study we have observed the evolution of the main parameters that affect camel meat quality (colour, lipid oxidation and shear force) when preserved in modified atmospheres with different mixtures of gas. For colour, however, values obtained indicated that MAP was the best of those tested. Modified atmosphere packaged fresh camel meat with high $\mathrm{CO}_{2}$ reduced the increasing rate of lipid oxidation during storage. Our study showed that even though oxidative rancidity (TBARS) increased with storage time in all packed samples, it did not result the deterioration of sensory quality in MAP. This indicates that lipid oxidation is not a major problem in MA-packaged fresh camel meat stored at $4^{\circ} \mathrm{C}$ up to 21 days. In summary, packaging with MAP $\left(60 \% \mathrm{CO}_{2}+40 \% \mathrm{~N}_{2}\right)$ of fresh camel meat accompanied by refrigeration storage enhanced product shelf life at least for 3 weeks without undesirable and detrimental effects on its sensory acceptability.

\section{Acknowledgements}

The authors extend their sincere gratitude to Islamic Azad University, Shahre-qods branch, Iran for having provided all facilities to conduct the above research work.

\section{References}

1. Narasimha Rao D, Sachindra NM (2002) Modified atmosphere and vacuum packaging of meat and poultry products. Food Reviews International 18: 263293.

2. Church N (1994) Development in modified-atmosphere packaging and related technologies. Trends in Food Science and Technology 5: 345-352.

3. Gill CO (1996) Extending the storage life of raw chilled meats. Meat Science 43: S99-S109.

4. Jeremiah LE, Gibson LL (2001) The influence of storage temperature and storage time on color stability, retail properties and case-life of retail-ready beef. Food Research International 34: 815-826.

5. Hood DE, Mead GC (1995) Storage atmo 'sferamodificada of carnesfrescas In: Packaged Food in Atmo'sferaModificada Ed A. Madrid Vicente 300-331.

6. El-Faer MZ, Rawdah TN, Attar KM, Dawson MV (1991) Mineral and proximate composition of the meat of the one-humped camel (Camelus dromedaries). Food Chemistry 42: 139-143.

7. Elgasim EA, Alkanhal MA (1992) Proximate composition, amino acids and inorganic minerals content of Arabian camel meat: comparative study. Food Chemistry 45: 1-4.

8. El-Gasim EA, El-Hag GA (1993) Carcass characteristics of the Arabian camel. Camel News Letter 9: 20-24.

9. Dawood AA (1995) Physical and sensory characteristics of Najdi-Camel meat Meat Science 39: 59-69.

10. Jouki M, Khazaei N (2011) Effects of Storage Time on Some Characteristics of Packed Camel Meat in Low Temperature. International Journal of Animal and Veterinary Advances 3: 460-464.

11. Jouki M, Khazaei N (2012) Color and oxidation changes in camel meat during storage. International Journal of Pharma and Bio Sciences 3: 164-170.

12. Witte VC, Krause GF, Bailey ME (1970) A new extraction method for determining 2-thiobarbituric acid values of pork and beef during storage. Journal of Food Science 35: 582-585.

13. CIE-ComissionInternacionale the lighting. Colorimetry: Official recommendations of the international commission on illumination (1976) Publication CIE No. 15 (E-1.3.1.) Paris, France: BoreauCentralde the CIE.

14. Peryam DR, Pilgrim FJ (1970) Hedonic scale method of measuring food preferences. Food Technology 11: 9-14.

15. Paul P, Venugopal V, Nair PM (1990) Shelf-life enhancement of lamb meat under refrigeration by gamma irradiation. J. Food Science 55: 856-866.

16. SAS/STAT (1988) User's guide, release 6.03 edn. Cary, NC: SAS Institute Inc

17. Wong JW, Hashimoto K, Shibamoto T (1995) Antioxidant activities of rosemary and sage extracts and vitamin $\mathrm{E}$ in a model meat system. Journal of Agricultural and Food Chemistry 43: 2707-2712

18. Yang A, Lanari MC, Brewster M, Tume RK (2002) Lipid stability and meat colou of beef from pasture- and grainfed cattle with or without vitamin $\mathrm{E}$ supplement. Meat Science 60: 41-50. 
Citation: Jouki M, Khazaei N (2012) Lipid Oxidation and Color Changes of Fresh Camel Meat Stored Under Different Atmosphere Packaging Systems. J Food Process Technol 3:189. doi:10.4172/2157-7110.1000189

Page 4 of 4

19. Gatellier P, Mercier Y, Juin H, Renerre M (2005) Effect of finishing mode (pasture -or mixed diet) on lipid composition, colour stability and lipid oxidation in meat from Charolais cattle. Meat Science 69: 175-186.

20. Fernandez J, Perez JA, Sayas E, Aranda V (2000) Characterization of the different sates of myoglobin in pork using color parameters and reflectance ratios. Journal of Muscle Foods 11: 157-116.

21. Mercier Y, Gatellier P, Viau M, Remignon H, Renerre M (1998) Effect of dietary fat and vitamin $\mathrm{E}$ on colour stability and on lipid and protein oxidation in turkey meat during storage. Meat Science 48: 301-318.
22. Moore VJ, Gill CO (1987) The $\mathrm{pH}$ and display life of chilled lamb after prolonged storage under vacuum or under $\mathrm{CO}_{2}$. New Zealand journal of agricultural research 30: 449-452.

23. Brody AL (1970) Shelf life of fresh meat. Modern packaging 1: 81-86.

24. Gariepy C, Amiot J, Simard RE, Boudreau A, Raymond DP (1986) Effect of vacuum-packing and storage in nitrogen and carbon dioxide atmospheres on the quality of fresh rabbit meat. Journal of Food Quality 9: 289-309.

25. Jeremiah LE (2001) Packaging alternatives to deliver fresh meats using shortor long-term distribution. Food Research International 34: 749-772. 